\title{
Segmentation of Processed Fruit Juice Consumers in Urban Uganda
}

\author{
Gabriel Elepu (Corresponding author) \\ Dept. of Agribusiness \& Natural Resource Economics, Makerere University \\ PO Box 7062, Kampala, Uganda
}

Tel: 256-782-758-887Ｅ-mail: elepu@caes.mak.ac.ug

Janet Nabisubi

Dept. of Agribusiness \& Natural Resource Economics, Makerere University

PO Box 7062, Kampala, Uganda

E-mail: jnabisubi@yahoo.com

Dick Sserunkuuma

Dept. of Agribusiness \& Natural Resource Economics, Makerere University

PO Box 7062, Kampala, Uganda

E-mail: sserunkuuma@caes.mak.ac.ug

Received: March 4, 2016 Accepted: April 22, 2016 Published: May 3, 2016

doi:10.5296/bms.v7i1.9409 URL: http://dx.doi.org/10.5296/bms.v7i1.9409

\begin{abstract}
This study was conducted to gain insights into processed fruit juice consumer segments in Uganda so as to assist local and foreign agribusinesses target and position their products. A market intercept survey of processed fruit juice consumers was conducted and segmentation of consumers was done using a combination of factor analysis and k-means clustering method. Five preference-based processed fruit juice consumer segments were identified, namely: Convenience Seekers, Health Conscious, Brand Conscious, Safety Conscious, and
\end{abstract}




\section{Macrothink}

Business Management and Strategy ISSN 2157-6068

Price Sensitive. While the demographics of these consumer segments did not differ, they tended to differ in their preferences and buying behaviours. Thus, fruit juice processing and distributing agribusinesses need to engage in strategic marketing by offering and communicating different products targeted to different consumer segments.

Keywords: Consumer segments, Processed fruit juice, Agribusinesses, Strategic marketing 


\section{Introduction}

Globally, processed fruit juice is being perceived and marketed as a healthy food product and, as such its demand is driven by increasing consumer awareness of health (PMR, 2015). On top of the list are pure (100\% fruit juice) and natural fruit juices with functional additives (vitamins and minerals) that command premium prices on the market. On the other end of the price/quality spectrum are low-priced, sugar-sweetened fruit punches that appeal most to the bottom-of-the-pyramid consumers that take it as a refreshing and thirst quenching drink. However, processed fruit juice has other valuable quality attributes that are preferred differently by consumers. These attributes include: freshness, taste/flavour, texture, shelf life, packaging material, brand, and origin (Weemaes and Reithmuller, 2001).

Based on their preferences for quality attributes, behaviours and demographics, processed fruit juice consumers have been segmented in China (Lee et al., 2015); United States (Bonilla, 2010); European Union (Sparke and Menrad, 2009; Baourakis et al., 2007; and Sorenson and Bogue, 2005). Common to all studies is the consumer segment that seeks for natural and nutritious fruit juices. Convenience and lower price seekers are other universal groups of consumers. Other idiosyncratic groups include brand, diet, and environment conscious consumers. Thus, as their marketing strategy, fruit juice processors and distributors operating in these regions have targeted and positioned their products accordingly.

In a recent survey of African consumers, Hattingh et al. (2012) concluded that urban consumers in Africa are "similar to those found anywhere else in the world: they are both brand and quality conscious, they seek out the latest trends but watch their budget, and they want a modern, attractive shopping environment." Linked to the above phenomenon is the rapid growth of supermarkets being experienced in the developing world (Reardon, 2011). Being patronized by mainly middle-income urban consumers, supermarkets provide an appropriate channel for distribution of processed fruit juice products. In Uganda, regional supermarket chains from Kenya and South Africa as well as locally-owned supermarkets are highly involved in the distribution of both imported and locally-produced processed fruit juice (Elepu, 2009).

The motivation of this study therefore was to segment processed fruit juice consumers in urban areas of Uganda. Understanding the profile of these consumers will assist both local and foreign agribusinesses involved in processing and distribution of processed juice products in Uganda to target them and position their products accordingly. Further, agribusinesses will also be able to identify critical and unique consumer needs and trends that are likely to influence the future direction of the processed fruit juice industry in Uganda.

\section{The State of Processed Fruit Juice Industry in Uganda}

The demand for processed fruit juice in Uganda currently exceeds its supply. Urbanization and growth in incomes in Uganda have led to increased demand for fresh fruit juice products, especially among nutrition and health conscious consumers. Much of the fruit juice demand is satisfied through imports from South Africa and Kenya. Uganda imports about 18.4 million 
liters of fresh fruit juice per year worth about US\$30 million and the annual growth in importation of fresh fruit juice, for the period 2002-2006, was reported at 56 percent to 135 percent (UIA, 2009).

In response to this market opportunity, fruit juice processing has recently begun in Uganda. There are seven certified fruit juice processors in Uganda with Britannia Allied Industries, Century Bottling Company (CBC), and Sameer Agriculture Livestock Ltd (SALL) being the dominant players (Kalungi, 2012). Britannia was the first big company to enter the market and has since introduced various fruit juice products under the Splash brand name. In 2011, $\mathrm{CBC}$, the bottlers of Coca-cola products added a juice processing line at its Namanve plant and started producing Minute Maid juice brand. In the same year, Sameer, a dairy processor diversified into fruit juice processing and launched the Daima juice brand. Moreover, plans are under way to build another fruit processing plant in eastern Uganda, a region where citrus fruit production has rapidly grown in recent years.

Whether imported or locally-made, processed fruit juice is distributed to consumers in urban areas through mainly supermarkets and retail shops although other minor outlets, such as restaurants, open/roadside markets, and social places, exist (Elepu, 2012). Supermarkets normally carry a wide variety of fruit juices compared to other outlets and probably that is why they are the major source of fruit juice to consumers.

\section{Methodology}

\subsection{Consumer Segmentation Methods}

Processed fruit juice consumers were segmented using a two-step cluster analysis method, which involved the use of factor analysis method in the first step and k-means clustering method in the second step (Aldenderfer and Blashfield, 1984). After consumer segments were generated, they were profiled using their demographic and behavioural characteristics. To do this, non parametric tests (F-test and Chi-square tests) were carried out to test for any significant differences among consumer segments in demographic and behavioural characteristics.

\subsection{Data Collection Methods and Analysis}

Data was collected in early 2012 from two shopping malls in Kampala metropolis, namely: Oasis and Ntinda. Oasis Mall is one of the largest shopping malls in Kampala housing Nakumatt, a supermarket chain from Kenya. It is adjacent to Garden City Mall where Uchumi, another supermarket chain from Kenya is located. Ntinda shopping mall is located in the suburban area of Kampala and has Quality supermarket, which is the largest local supermarket chain. Nakumatt and Quality supermarkets stocked various brands of processed fruit juice and juice squashes, both local and foreign. These supermarkets also offer a convenient avenue for intercepting processed fruit juice shopping consumers.

During the consumer survey, a total of 396 consumers were randomly intercepted at the entrance to the supermarket. From each consumer, data on their behaviour, preferences, and 


\section{Ml Macrothink}

demographics were collected using a structured questionnaire. After data entry and cleaning, the total number of usable surveys was 382. The statistical package for social scientists (SPSS) computer software was used to generate descriptive statistics and non-parametric tests, and perform both factor and cluster analyses.

\section{Results and Discussion}

\subsection{Consumer Preferences for Attributes of Processed Fruit Juice in Uganda}

Consumers were asked to rate the importance of 16 attributes of fruit juice in influencing what they normally buy on a 7 -point Likert scale $(1=$ Not at all important to $7=$ Extremely important). These attributes included: naturalness/pureness, safety, type of packaging material, resealability of package, transparency of package, package attractiveness, package size, flavour/taste, shelf life, brand, price, vitamin $\mathrm{C}$ label, no added sugar label, calories and nutrients content, country of origin, juice and production technology. Figure 1 below shows that consumers rated as important all attributes except country of origin and production technology of juice. Highly rated attributes were pureness, safety and shelf life of fruit juice.

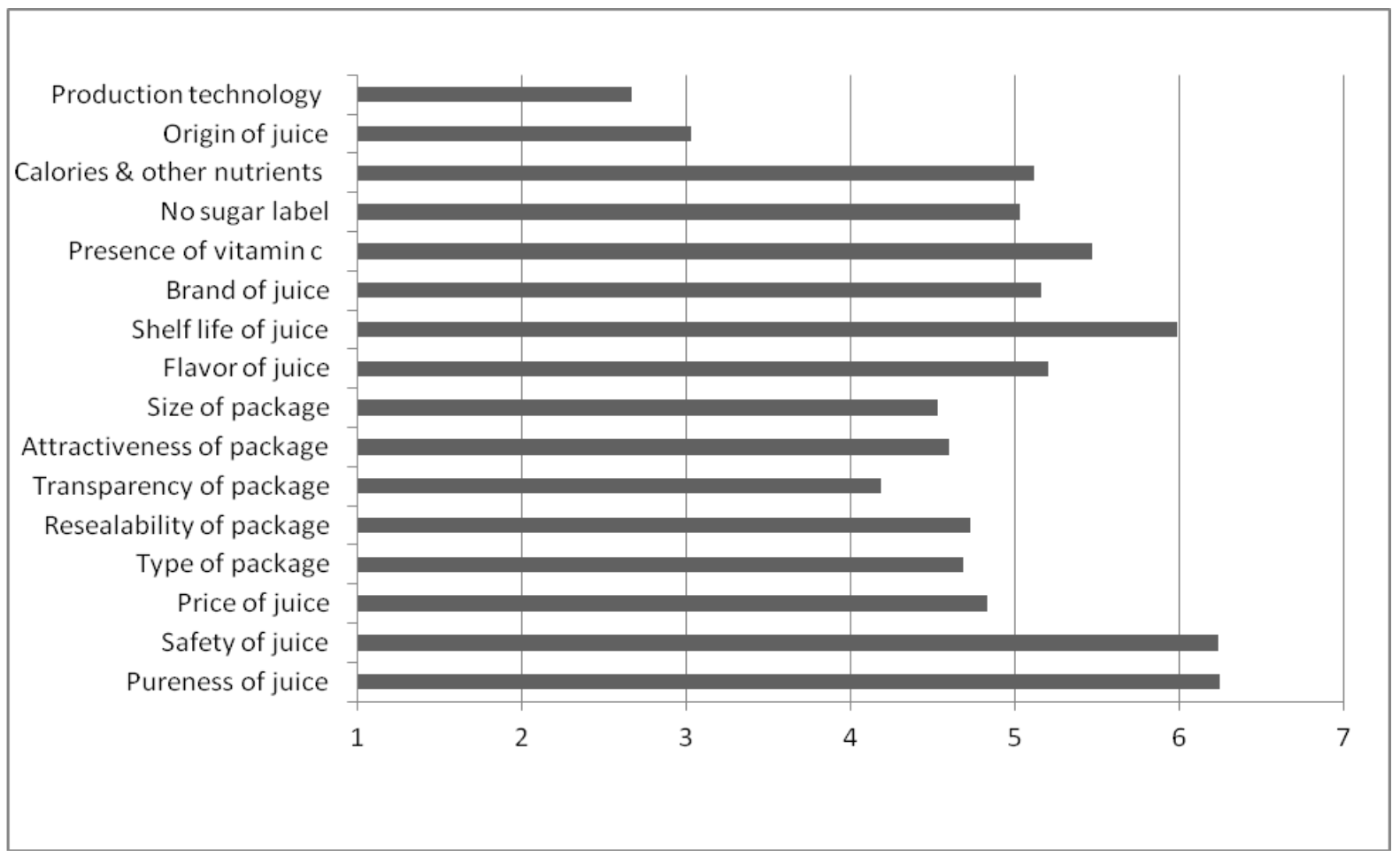

Figure 1. Consumer importance ratings of attributes of processed fruit juice

Factor analysis was used to reduce the 16 attributes of fruit juice used in the survey into 5 component factors. The principal components analysis extraction method and the varimax rotation method were used since they lead to the derivation of uncorrelated factors (Kim and Mueller, 1978a \& b).

The Kaiser-Meyer-Olkin (KMO) measure of sampling adequacy was 0.624 indicating that the sample size was adequate for factor analysis. The Bartlett's test of sphericity was was also 


\section{Mll Macrothink}

significant (Chi-square $=808.473, d f=120, p=0.000)$ and this implied that the correlation matrix was not an identity matrix. The Bartlett's test further showed that the factor model was suitable.

Using the Kaiser criterion, the optimal number of component factors, with eigenvalues exceeding 1.0, were five accounting for $52 \%$ of the total variance. In ascending order, the extracted component factors were called: Nutrition and health, Packaging of juice, Origin of juice, Safety of juice, and Price of juice. Table 1 below shows component factors, factor loadings, Cronbach's alpha, and communality associated with the factor model.

Table 1. Component factors of processed fruit juice attributes

\begin{tabular}{|l|r|r|r|r|r|r|}
\hline \multirow{2}{*}{ Attribute } & \multicolumn{5}{|c|}{ Component factors } & \multirow{2}{*}{ Communality } \\
\cline { 2 - 6 } & $\begin{array}{c}\text { Nutrition } \\
\text { \& health }\end{array}$ & Packaging & Origin & Safety & Price & \\
\hline Pureness of juice & .040 & .115 & .029 & $\mathbf{. 7 0 3}$ & -.154 & .534 \\
\hline Safety of juice & .090 & -.191 & .202 & $\mathbf{. 6 9 4}$ & -.017 & .567 \\
\hline Price of juice & .020 & -.030 & .101 & -.190 & $\mathbf{. 7 5 1}$ & .612 \\
\hline Type of package & .187 & $\mathbf{. 4 1 3}$ & -.037 & .142 & $\mathbf{. 4 5 1}$ & .431 \\
\hline Resealability of package & .110 & $\mathbf{. 6 6 3}$ & -.028 & .092 & .062 & .465 \\
\hline Transparency of package & .112 & $\mathbf{. 7 2 7}$ & .064 & -.169 & -.217 & .621 \\
\hline Attractiveness of package & -.108 & $\mathbf{. 6 1 6}$ & .119 & .071 & .128 & .427 \\
\hline Size of package & -.199 &. $\mathbf{4 2 2}$ & .098 & .197 & $\mathbf{. 4 1 2}$ & .436 \\
\hline Flavour of juice & -.280 & .035 & .270 & $\mathbf{. 4 2 7}$ & .327 & .441 \\
\hline Shelf life of juice & -.100 & .273 & -.193 & $\mathbf{. 5 0 2}$ & .107 & .385 \\
\hline Brand of juice & .033 & -.038 &. $\mathbf{4 0 5}$ & .015 & .229 & .219 \\
\hline Vitamin C and others & $\mathbf{. 6 5 6}$ & .107 & .133 & .152 & .196 & .521 \\
\hline No sugar label & $\mathbf{. 8 0 8}$ & .012 & -.109 & -.092 & -.039 & .675 \\
\hline Calories \& other nutrients & $\mathbf{. 8 2 0}$ & -.019 & .006 & -.045 & -.095 & .684 \\
\hline Origin of juice & -.059 & .099 & $\mathbf{. 8 1 5}$ & -.006 & -.155 & .701 \\
\hline Production technology & .022 & .100 & $\mathbf{. 7 7 4}$ & .121 & .106 & .534 \\
\hline Cronbach's $\alpha$ & .690 & .581 & .520 & .426 & .366 & \\
\hline
\end{tabular}

The above component factors were interpreted by taking factor loadings above 0.6 to be high and those from 0.4 to 0.6 to be moderate. Nutrition and health was highly loaded with three attributes of fruit juice: calories and nutrients content, no added sugar label, and vitamin $\mathrm{C}$ label. Packaging of juice was highly loaded with transparency and resealability of package and moderately loaded with package attractiveness, package size, and type of packaging material. Origin of juice was highly loaded with country of origin and production technology of juice and moderately loaded with brand of juice. Safety of juice was highly loaded with pureness and safety of juice and moderately loaded with shelf life and flavour of juice. Price of juice was highly loaded with price of juice and moderately so with type and size of package. 


\subsection{Segments of Processed Fruit Juice Consumers}

Processed fruit juice consumers were then clustered based on standardized factor scores generated during factor analysis. To ensure orthogonality of component factors, Anderson-Rubin criterion was used to compute factor scores (Kim and Mueller, 1978a). The k-means method was used to obtain clusters of consumers. For two, three, and four clusters, some base variables were insignificant implying these clusters were not distinct. In contrast, five and six clusters were distinct. However, using economic intuition and empirical evidence, the optimum number of clusters was taken to be five. The identified consumer segments were then designated the following names: Convenience Seekers, Health Conscious, Brand Conscious, Safety Conscious, and Price Sensitive.

Convenience Seekers formed the largest group with 115 (30\%) consumers, while Price Sensitive consumers were the smallest segment with $48(13 \%)$ consumers. Sizes of other consumer segments were as follows: Health conscious (86), Brand Conscious (71), and Safety Conscious (62) as shown in Table 2 below. Convenience Seekers considered packaging of juice, nutrition and health, and to a lesser extent safety of juice as important factors in driving them to buy processed fruit juice. Health Conscious were motivated by nutrition and health, safety and price of juice. Though they were highly motivated by the origin of juice, Brand Conscious consumers also considered all the other factors as important. Safety Conscious consumers deemed safety of juice and to a certain extent price of juice as pertinent factors. Price Sensitive consumers were attracted by price of juice as well as packaging of juice.

Table 2. Segments of processed fruit juice consumers

\begin{tabular}{|l|r|r|r|r|r|}
\hline Factor & $\begin{array}{c}\text { Convenience } \\
\text { Seekers }\end{array}$ & $\begin{array}{c}\text { Health } \\
\text { Conscious }\end{array}$ & $\begin{array}{c}\text { Brand } \\
\text { Conscious }\end{array}$ & $\begin{array}{c}\text { Safety } \\
\text { Conscious }\end{array}$ & $\begin{array}{c}\text { Price } \\
\text { Sensitive }\end{array}$ \\
\hline Nutrition and health & $\mathbf{. 3 5 3 1 3}$ & $\mathbf{. 5 7 6 1 8}$ & $\mathbf{. 2 3 7 9 8}$ & -1.67747 & -.06365 \\
\hline Packaging of fruit juice & $\mathbf{. 6 0 6 5 5}$ & -1.05980 & $\mathbf{. 3 0 4 1 4}$ & -.21815 & $\mathbf{. 2 7 7 5 3}$ \\
\hline Origin of fruit juice & -.40596 & -.39052 & $\mathbf{1 . 4 6 5 5 4}$ & -.17173 & -.27367 \\
\hline Safety of fruit juice & $\mathbf{. 0 4 9 5 0}$ & $\mathbf{. 2 3 7 5 8}$ & $\mathbf{. 3 6 5 0 1}$ & $\mathbf{. 5 5 2 1 9}$ & -1.79741 \\
\hline Price of fruit juice & -.56242 & $\mathbf{. 1 7 9 8 3}$ & $\mathbf{. 3 0 9 1 6}$ & $\mathbf{. 0 4 0 6 2}$ & $\mathbf{. 5 1 5 5 1}$ \\
\hline Total & $\mathbf{1 1 5}$ & $\mathbf{8 6}$ & $\mathbf{7 1}$ & $\mathbf{6 2}$ & $\mathbf{4 8}$ \\
\hline \% of Total & $\mathbf{3 0}$ & $\mathbf{2 2}$ & $\mathbf{1 9}$ & $\mathbf{1 6}$ & $\mathbf{1 3}$ \\
\hline
\end{tabular}

Note: Factor scores have mean 0 and standard deviation 1.

Consumer segments were validated by use of split-half test and performing multivariate analysis of variance (MANOVA) of base variables (Aldenderfer and Blashfield, 1984). Based on the MANOVA test, the identified segments were distinct since the significance tests on all base variables were significant (Table 3). 
Table 3. MANOVA of component factors

\begin{tabular}{|l|r|r|r|r|r|r|}
\hline \multirow{2}{*}{ Factor } & \multicolumn{2}{|c|}{ Cluster } & \multicolumn{1}{c|}{ Error } & \multicolumn{2}{c|}{ F } & Sig. \\
\cline { 2 - 7 } & $\begin{array}{c}\text { Mean } \\
\text { Square }\end{array}$ & df & $\begin{array}{c}\text { Mean } \\
\text { Square }\end{array}$ & df & $\begin{array}{c}\text { Mean } \\
\text { Square }\end{array}$ & \multicolumn{1}{c|}{ df } \\
\hline Nutrition and health & 55.392 & 4 & .423 & 377 & 130.983 & .000 \\
\hline Packaging of fruit juice & 38.029 & 4 & .607 & 377 & 62.639 & .000 \\
\hline Origin of fruit juice & 47.496 & 4 & .507 & 377 & 93.742 & .000 \\
\hline Safety of fruit juice & 47.143 & 4 & .510 & 377 & 92.363 & .000 \\
\hline Price of fruit juice & 14.701 & 4 & .855 & 377 & 17.201 & .000 \\
\hline
\end{tabular}

\subsubsection{Demographic Characteristics of Consumer Segments}

Consumer segments were not significantly different in all the demographic characteristics including sex, age, education, household size, occupation, income, and nationality. In general, about $57 \%$ of the respondents were male while $43 \%$ were female. They tended to be younger and more educated with $42 \%$ of them being in the age group of 25-34 and over a half (52\%) of them having reached some university college. Most (78\%) of them were employed either by self or some organization. A majority (87\%) of them was Ugandans and the rest were foreigners which included mainly Kenyans. In terms of monthly household income, they were fairly distributed across all income categories (Table 4). 
Table 4. Demographic characteristics of consumer segments, $\%$

\begin{tabular}{|c|c|c|c|c|c|c|c|}
\hline Characteristic & $\begin{array}{c}\text { Convenience } \\
\text { Seekers }\end{array}$ & $\begin{array}{c}\text { Health } \\
\text { Conscious }\end{array}$ & $\begin{array}{c}\text { Brand } \\
\text { Conscious }\end{array}$ & $\begin{array}{c}\text { Safety } \\
\text { Conscious }\end{array}$ & $\begin{array}{c}\text { Price } \\
\text { Sensitive }\end{array}$ & Total & $\chi^{2}$ \\
\hline \multicolumn{8}{|l|}{ Sex } \\
\hline Male & 52.6 & 60.7 & 59.2 & 52.5 & 61.7 & 56.8 & \multirow[t]{2}{*}{2.420 (n.s) } \\
\hline Female & 47.4 & 39.3 & 40.8 & 47.5 & 38.3 & 43.2 & \\
\hline \multicolumn{8}{|l|}{ Age } \\
\hline Under 25 & 30.4 & 33.7 & 27.9 & 40.0 & 33.3 & 32.6 & \multirow{4}{*}{17.038 (n.s) } \\
\hline $25-34$ & 44.3 & 43.0 & 39.7 & 36.7 & 43.7 & 41.9 & \\
\hline $35-44$ & 17.4 & 14.0 & 26.5 & 20.0 & 16.7 & 18.6 & \\
\hline 45 or over & 7.9 & 9.3 & 5.9 & 3.3 & 6.3 & 6.9 & \\
\hline \multicolumn{8}{|l|}{ Education } \\
\hline None & 0.0 & 0.0 & 0.0 & 1.7 & 0.0 & 0.3 & \multirow{5}{*}{17.616 (n.s) } \\
\hline Primary & 0.9 & 4.7 & 1.5 & 3.3 & 4.2 & 2.7 & \\
\hline Secondary & 25.7 & 23.5 & 20.6 & 25.0 & 29.8 & 24.7 & \\
\hline Tertiary & 27.4 & 22.4 & 19.1 & 11.7 & 14.9 & 20.6 & \\
\hline University & 46.0 & 49.4 & 58.8 & 58.3 & 51.1 & 51.7 & \\
\hline \multicolumn{8}{|l|}{ Occupation } \\
\hline Student & 16.5 & 15.3 & 14.3 & 29.0 & 12.5 & 17.4 & \multirow{4}{*}{27.231 (n.s) } \\
\hline Employed & 77.4 & 82.3 & 81.5 & 67.8 & 77.1 & 77.6 & \\
\hline Unemployed & 4.3 & 2.4 & 2.8 & 1.6 & 10.4 & 3.9 & \\
\hline Retired & 1.7 & 0.0 & 1.4 & 1.6 & 0.0 & 1.1 & \\
\hline \multicolumn{8}{|l|}{ Nationality } \\
\hline Ugandan & 90.1 & 88.0 & 92.8 & 80.6 & 81.3 & 87.4 & \multirow[t]{2}{*}{6.765 (n.s) } \\
\hline Other & 9.9 & 12.0 & 7.2 & 9.4 & 18.7 & 12.6 & \\
\hline \multicolumn{8}{|l|}{ Income } \\
\hline$<$ Ush0.5 m & 29.6 & 42.0 & 35.4 & 29.2 & 41.5 & 35.0 & \multirow{3}{*}{12.232 (n.s) } \\
\hline USh0.5-1 m & 51.9 & 38.2 & 40.0 & 39.5 & 26.8 & 41.7 & \\
\hline$>$ Ush1 m & 18.5 & 19.8 & 24.6 & 31.3 & 31.7 & 23.3 & \\
\hline
\end{tabular}

Note: Level of statistical significance: $n . s$ is not significant; and Exchange rate: 1 US\$ = Ush2400.

\subsubsection{Behavioural Characteristics of Consumer Segments}

Fruit juice consumer segments differed in shopping behaviour as shown in Table 5 below. Health Conscious consumers appeared to be more regular consumers of fruit juice than other consumer segments. Weekly per capita consumption of fruit juice was highest among these consumers and stood at 3.08 litres. Similarly, their weekly expenditure on fruit juice of Ush15,473 (US\$6.45) was also the highest of all consumer segments. Although the supermarket remained to be the major source of fruit juice for all consumer segments, retail shops were also patronized by most Price Sensitive and Convenience Seekers.

Approximately $73 \%$ of Price Sensitive consumers and $66 \%$ of Convenience Seekers said they bought their fruit juice from retail shops. Consumption of fruit juice often took place both at home and away from home for most consumers in all segments except Safety Conscious and Brand Conscious. For example, $20 \%$ of Brand Conscious consumers always took fruit juice only at home while $21 \%$ of Safety Conscious consumers had it exclusively away from home. While refreshment was the main reason for consumption of fruit juice for all consumer segments, Safety Conscious consumers were peculiar when it came to other motives, namely: 
thirst, nutrition, and health. A higher proportion (32\%) of Safety Conscious consumers bought fruit juice to quench their thirst and only $19 \%$ of them were motivated by nutrition and health benefits.

Table 5. Behavioural characteristics of consumer segments

\begin{tabular}{|c|c|c|c|c|c|c|c|}
\hline Characteristic & $\begin{array}{c}\text { Convenience } \\
\text { Seekers }\end{array}$ & $\begin{array}{c}\text { Health } \\
\text { Conscious }\end{array}$ & $\begin{array}{c}\text { Brand } \\
\text { Conscious }\end{array}$ & $\begin{array}{c}\text { Safety } \\
\text { Conscious }\end{array}$ & $\begin{array}{c}\text { Price } \\
\text { Sensitive }\end{array}$ & Total & $\begin{array}{c}\chi^{2} / \mathrm{F}- \\
\text { statistic }\end{array}$ \\
\hline \multicolumn{8}{|l|}{ Frequency (\%) } \\
\hline Regularly & 54.6 & 67.1 & 59.7 & 60.7 & 76.6 & 62.2 & \multirow[t]{2}{*}{$7.871^{*}$} \\
\hline Irregularly & 45.4 & 32.9 & 40.3 & 39.3 & 23.4 & 37.8 & \\
\hline Amount (L/wk) & 2.36 & 3.08 & 2.50 & 2.01 & 2.07 & 2.46 & $2.866 * *$ \\
\hline Money (Ush/wk) & 12,233 & 15,473 & 12,554 & 10,293 & 10,538 & 12,504 & $2.393 * *$ \\
\hline \multicolumn{8}{|l|}{ Source (\%) } \\
\hline Open market & 1.8 & 3.5 & 0.0 & 4.9 & 2.1 & 2.4 & 4.072 (n.s) \\
\hline Restaurant & 3.5 & 5.8 & 7.1 & 8.2 & 0.0 & 5.0 & 5.156 (n.s) \\
\hline Retail shops & 65.8 & 45.3 & 37.1 & 36.1 & 72.9 & 52.0 & $31.017 * * *$ \\
\hline Supermarket & 93.0 & 95.3 & 90.0 & 86.9 & 91.7 & 91.8 & 3.919 (n.s) \\
\hline Social place & 1.8 & 0.0 & 1.4 & 3.3 & 2.1 & 1.6 & 2.618 (n.s) \\
\hline \multicolumn{8}{|l|}{ Place of use (\%) } \\
\hline At home & 7.0 & 9.4 & 20.0 & 16.4 & 6.3 & 11.3 & \multirow{3}{*}{$26.099 * * *$} \\
\hline Away from home & 7.0 & 7.1 & 17.1 & 21.3 & 8.3 & 11.3 & \\
\hline Both & 86.0 & 83.5 & 62.9 & 62.3 & 85.4 & 77.3 & \\
\hline \multicolumn{8}{|l|}{ Reason (\%) } \\
\hline Thirst & 13.0 & 18.6 & 24.3 & 32.3 & 4.3 & 18.4 & $17.992 * * *$ \\
\hline Nutrition & 47.8 & 47.7 & 40.0 & 19.4 & 44.7 & 41.3 & $16.047 * * *$ \\
\hline Health & 58.3 & 57.0 & 38.6 & 14.5 & 59.6 & 47.4 & $40.479 * * *$ \\
\hline Refreshment & 74.8 & 75.6 & 61.4 & 69.4 & 80.9 & 72.1 & 6.942 (n.s) \\
\hline
\end{tabular}

Note: Level of statistical significance - *** (1\%), ** (5\%), * (10\%), and n.s (not significant); and Exchange rate: 1 US\$ = Ush2400.

\subsubsection{Type of Processed Fruit Juice Preferred by Consumer Segments}

Across all consumer segments, there was no significant difference in flavour or taste of fruit juice often bought. In general, mango was the frequently bought flavour of juice as indicated by over $67 \%$ of the consumers. Three other flavours that were regularly bought by a significant proportion of consumers included: apple (38\%), pineapple $(29 \%)$, orange $(28 \%)$, passion (13\%), and strawberry (13\%) as shown in Table 6 below. Other fruit flavours that were also liked but by only a few consumers included: guava, blackcurrant, banana, red grape, white grape, lemon, tropical, hibi, and litchi. Although not all consumers seemed not to be very keen on fruit juice concentration, about $44 \%$ of them claimed they always bought $100 \%$ fruit juice. A majority (73\%) of the consumers often purchased chilled/ refrigerated juices 


\section{Ml Macrothink}

Business Management and Strategy

ISSN 2157-6068

2016, Vol. 7, No. 1

perhaps for immediate consumption. However, a big majority of Convenience Seekers and Price Sensitive consumers always bought fruit juice in small portion sizes of 0.5 litres or less.

Table 6. Preferences of consumer segments for attributes of processed fruit juice, $\%$

\begin{tabular}{|c|c|c|c|c|c|c|c|}
\hline Attribute & $\begin{array}{c}\text { Convenience } \\
\text { Seekers }\end{array}$ & $\begin{array}{c}\text { Health } \\
\text { Conscious }\end{array}$ & $\begin{array}{c}\text { Brand } \\
\text { Conscious }\end{array}$ & $\begin{array}{c}\text { Safety } \\
\text { Conscious }\end{array}$ & $\begin{array}{c}\text { Price } \\
\text { Sensitive }\end{array}$ & Total & $\chi^{2}$ statistic \\
\hline \multicolumn{8}{|l|}{ Flavor } \\
\hline Mango & 67.0 & 70.9 & 66.2 & 71.0 & 58.3 & 67.3 & 2.692 (n.s) \\
\hline Apple & 38.3 & 40.7 & 43.7 & 33.9 & 27.1 & 37.7 & 4.110 (n.s) \\
\hline Pineapple & 25.2 & 27.9 & 32.4 & 29.0 & 31.3 & 28.5 & 1.337 (n.s) \\
\hline Orange & 29.6 & 27.9 & 33.8 & 16.1 & 27.1 & 27.5 & 5.694 (n.s) \\
\hline Passion & 8.7 & 11.6 & 15.5 & 14.5 & 18.8 & 12.8 & 3.981 (n.s) \\
\hline Strawberry & 11.6 & 18.6 & 7.0 & 14.5 & 10.4 & 12.6 & 5.409 (n.s) \\
\hline Other & 36.5 & 37.2 & 32.4 & 40.3 & 39.6 & 36.9 & 1.090 (n.s) \\
\hline \multicolumn{8}{|l|}{ Juice Conc. } \\
\hline $100 \%$ & 39.1 & 38.8 & 52.2 & 51.7 & 41.9 & 43.8 & \multirow{3}{*}{9.643 (n.s) } \\
\hline$<100 \%$ & 17.4 & 11.8 & 10.1 & 5.0 & 12.5 & 12.2 & \\
\hline Both & 43.5 & 49.4 & 37.7 & 43.3 & 45.8 & 44.0 & \\
\hline \multicolumn{8}{|l|}{ Portion size } \\
\hline 0.51 or less & 87.5 & 59.7 & 60.5 & 52.9 & 73.9 & 66.4 & \multirow{3}{*}{$25.066 * * *$} \\
\hline$>0.51$ & 10.4 & 37.1 & 38.4 & 47.1 & 24.3 & 32.0 & \\
\hline Both & 2.1 & 3.2 & 1.2 & 0.0 & 1.7 & 1.6 & \\
\hline \multicolumn{8}{|l|}{ Type } \\
\hline Chilled & 72.2 & 75.3 & 76.1 & 76.7 & 64.6 & 73.4 & \multirow{3}{*}{$9.100(\mathrm{n} . \mathrm{s})$} \\
\hline Non chilled & 14.8 & 10.6 & 9.9 & 3.3 & 18.8 & 11.6 & \\
\hline Both & 13.0 & 14.1 & 14.1 & 20.0 & 16.7 & 15.0 & \\
\hline \multicolumn{8}{|l|}{ Brand } \\
\hline Splash & 76.5 & 80.2 & 85.5 & 82.0 & 79.2 & 80.2 & 2.357 (n.s) \\
\hline Ribena & 42.6 & 30.2 & 27.5 & 16.4 & 33.3 & 31.7 & $13.627 * * *$ \\
\hline Minute maid & 22.6 & 25.6 & 20.3 & 23.0 & 16.7 & 22.2 & 1.599 (n.s) \\
\hline Del Monte & 20.0 & 22.1 & 14.5 & 24.6 & 25.0 & 20.8 & 2.839 (n.s) \\
\hline Ceres & 19.1 & 22.4 & 15.9 & 9.8 & 12.5 & 16.9 & 5.073 (n.s) \\
\hline Quencher & 16.5 & 17.4 & 10.1 & 9.8 & 12.5 & 14.0 & 3.276 (n.s) \\
\hline Other & 16.5 & 23.3 & 21.7 & 18.0 & 14.6 & 19.0 & $2.453(\mathrm{n} . \mathrm{s})$ \\
\hline
\end{tabular}

Note: Level of statistical significance - *** (1\%) and n.s (not significant).

4.2.4 Other Behaviours of Fruit Juice Consumer Segments

Consumer segments also differed significantly in consumption of non processed fruit juice, fruits, fruit flavoured imitator drinks, soda, dairy products, iced tea, energy drinks, and sparkling drinks. Consumption of fresh and dried fruits did not vary across consumer 
segments. However, there were significant differences in consumption of unpacked fruit juice, canned fruits, fruit flavoured drinks, soda, dairy products, iced tea, energy drinks, and sparkling drinks across consumer segments as shown in Table 7 below. For instance, more (80\%) Safety Conscious consumers consumed non processed juice and fewer (55\%) of them consumed fruit flavoured imitator drinks than other consumer segments.

Consumers avoided unpacked juice especially that on the market citing safety issues. Consumption of canned and dried fruits was low perhaps because of lack of availability of these products in the market. Moreover, consumption of fruit flavoured imitator drinks, soda, and dairy products, was higher than that of fruit flavoured iced tea, energy drinks, and sparkling drinks.

Table 7. Consumption of fruits and fruit flavoured products by consumer segments, $\%$

\begin{tabular}{|l|r|r|r|r|r|r|r|}
\hline Product & $\begin{array}{r}\text { Convenien- } \\
\text { ce Seekers }\end{array}$ & $\begin{array}{c}\text { Health } \\
\text { Conscious }\end{array}$ & $\begin{array}{c}\text { Brand } \\
\text { Conscious }\end{array}$ & $\begin{array}{c}\text { Safety } \\
\text { Conscious }\end{array}$ & $\begin{array}{c}\text { Price } \\
\text { Sensitive }\end{array}$ & $\begin{array}{c}\text { Total } \\
\chi^{\mathbf{2}} / \mathbf{F}- \\
\text { statistic }\end{array}$ \\
\hline Unpacked juice & 30.4 & 40.0 & 65.2 & 80.0 & 33.3 & 47.3 & $56.735^{* * *}$ \\
\hline Fresh fruits & 98.3 & 96.5 & 93.0 & 98.4 & 97.1 & 96.9 & 7.393 (n.s) \\
\hline Dried fruits & 27.8 & 25.6 & 32.9 & 21.3 & 35.4 & 28.2 & 10.221 (n.s) \\
\hline Canned fruits & 7.8 & 11.9 & 24.6 & 19.4 & 20.0 & 15.2 & $17.642^{* * *}$ \\
\hline Imitator drinks & 86.7 & 84.9 & 64.3 & 54.8 & 89.6 & 77.3 & $58.353^{* * *}$ \\
\hline Soda & 97.3 & 96.5 & 97.1 & 94.9 & 100.0 & 97.0 & $15.644 * *$ \\
\hline Dairy products & 72.2 & 69.6 & 77.1 & 71.0 & 72.9 & 72.2 & $19.116^{* *}$ \\
\hline Iced tea & 29.6 & 44.2 & 33.3 & 19.4 & 29.2 & 31.8 & $15.938^{* *}$ \\
\hline Energy drinks & 33.9 & 51.2 & 50.0 & 51.6 & 27.1 & 42.8 & $15.857^{* *}$ \\
\hline Sparkling drinks & 29.6 & 47.1 & 50.7 & 46.8 & 25.0 & 39.6 & $26.131^{* * *}$ \\
\hline
\end{tabular}

Note: Level of statistical significance - *** (1\%), ** (5\%), and n.s (not significant).

\subsection{Discussion}

Although the behaviours and motives of fruit juice consumers in Uganda and other countries are quite similar, they are demographically different. For example, Bonilla (2010) segmented $100 \%$ fruit juice consumers in the United States (US) into five groups based on their lifestyles and behaviours: Health Conscious; Environmentally Conscious and Information Seekers; Price Conscious; Diet Product Users; and Convenience Product Users. In contrast, Lee et al. (2015) clustered Chinese fruit juice consumers into three segments: Health Conscious, Premium Product, and Long Product Shelf-life. This shows that health, price, and convenience are important motives driving the consumption of fruit juice in the US and China as well as in Uganda. From Table 4 above, equivalent consumer segments (Convenience Seekers, Health Conscious, and Price Sensitive) were also identified in Uganda. But, what is interesting of these consumer segments is that they are demographically different from those existing in the US. Across all segments, fruit juice consumers tended to be younger and educated perhaps reflecting typical supermarket shoppers in Uganda as found in 
an earlier study (Elepu, 2009) or suggesting the different population structures in the two countries. In the US, Health Conscious consumers were mainly older women aged 65 years and above with some education and low-to-moderate incomes; Convenience Product Users were well-educated men aged below 44 years and with moderate incomes; Price Conscious consumers were mainly lowly educated females aged 35-64 years and with low incomes.

Diet product usage and environmental motives were not considered in this study owing to the non existence of fruit juice package recycling, lack of organic labels on fruit juices, and low use of diet products among consumers in Uganda. In the US, there were Environmentally Conscious and Information Seekers and Diet Product Users. While Environmentally Conscious and Information Seekers tended to be married women aged 55-64 years with some education and moderate to high incomes, Diet Product Users were mostly men aged 45-64 years with some level of education and moderate to high incomes. However, what seems to concern some fruit juice consumers most in Uganda were safety and origin of fruit juice and thus, existence of Safety Conscious and Brand Conscious consumers.

Similarly, fruit juice consumers segments in Uganda are also somehow comparable to functional fruit juice consumer segments identified by Sparke and Menrad (2009) in the European Union (EU) and chilled orange juice consumer segments identified by Sorenson and Bogue (2005) in Ireland in their buying motives, especially health and price (cost) motives. Though the focus was on functional fruit juice, Sparke and Menrad identified eight segments of consumers based on their buying/refusal motives and trust in actors. There were five buyer segments (Hesitating Unmotivated, Enlightened and Convinced, Reasonable Health-oriented, Impressed Testers, and Enthusiastic Beauty-oriented) and three non buyer segments (Enlightened Ignoring, Mistrustful Sceptical, and Cost-conscious Prevented). Reasonable Health-oriented consumers were mostly professional women aged 40-60 years, and with middle to high incomes, while Cost-conscious Prevented consumers were older than 60 years, had no children, and had low to very low incomes. However, the profiles of Reasonable Health-oriented and Cost-conscious Prevented consumers closely matched that of Nutrition Conscious and Price conscious consumers identified by Bonilla in the US. Segments of chilled orange juice consumers in Ireland identified by Sorenson and Bogue (2005) were also more similar to those in EU and US than Uganda although buying motives such as functionality, price were common in all countries.

Finally, Ugandan consumers seem to possess somehow different preferences for attributes of fruit juices compared to consumers in other countries, and this situation appears to vary from country to country. As seen earlier, mango, apple, pineapple, and orange in that order were the most preferred flavours across all consumer segments in Uganda. Chilled juice in small packages (half-litre package or less) was bought by most Ugandan consumers with mixed enthusiasm on fruit juice concentration. Exceptionally, consumers in India have almost the same preferences for flavour of fruit juices as those in Uganda. Mango, apple, orange, pineapple, and straw berry were the most preferred fruit juice flavours in India (Hirekenchanagoudar, 2008). 
In contrast, Baourakis et al. (2007) in a cross-country comparative study found that orange and mixed fruit flavours were the most preferred in both countries followed by peach and apple flavours in Greece and Netherlands, respectively. Most consumers in Greece and Netherlands preferred $100 \%$ juice, although some of them favoured 'all kinds of juices', up to $40 \%$ juice, and sugar added juice. Most (73\%) of the Dutch consumers preferred half-litre package while more than one-half $(55 \%)$ of Greek consumers favoured one-litre packages. The preferred time duration of fruit juice also differed between countries: short-life in Greece and long-life in Netherlands.

The disparity in consumer preferences for attributes of fruit juice among countries could be attributed to differences in socio-cultural environment among other factors. Wright et al. (2001) examined the influence of culture on food taste preferences and discovered that taste in food reflected in part the consumer's social and cultural origins, social ambitions and the cultural capital acquired, either as part of their upbringing or more deliberately. Since global distribution of fruits is varied depending on whether they are tropical or temperate and, so could be consumer preferences for fruit flavours. Consumer preferences for other attributes, such as size of package of processed fruit juice, might be varying due to differences in household size and to whether it is bought for immediate or home consumption.

\section{Conclusion}

Knowledge of existing consumer segments have far reaching marketing implications for agribusinesses to appropriately target and position their products in the processed juice market in Uganda. To satisfy Convenience Seekers, pack fruit juice in attractive, transparent and resealable packages of various sizes. For the Health Conscious segment, provide them with sugar free and low calorie, fruit juice enhanced with vitamins and minerals. However, nutrition and health benefits need to be clearly communicated to this segment. Safety Conscious consumers need to be assured fruit juice products meet quality and safety standards. Brand Conscious consumers will be better served through building strong brands of fruit juice. Development of a variety of fruit juice products based on portion size, fruit juice concentration, type of packaging, flavour, offered at a broad price spectrum will appeal to Price Sensitive consumer segments. Furthermore, to reach any of these consumer segments, fruit juice products need to be distributed through both supermarkets (local and regional chains) and retail shops.

\section{Acknowledgement}

The research was financed by the African Economic Research Consortium (AERC) through the Faculty Research Grant.

\section{References}

Aldenderfer, M. S., \& Blashfield, R. K. (1984), Cluster analysis. Newbury Park: Sage Publications Inc.

Bonilla, T. (2010). Analysis of consumer preferences toward 100\% fruit juice packages and 
labels. Unpublished thesis, Louisiana State University and Agricultural and Mechanical College, Baton Rouge, LA.

Elepu, G. (2009). The growth of supermarkets and its implications for smallholders in Uganda. Per Pinstrup-Andersen and Fuzhi Cheng (eds.), Food Policy for Developing Countries: Case Studies, Cornell University, Ithaca, New York, 9 pp. http://cip.cornell.edu/dns.gfs/1256051512

Elepu, G. (2012). Innovation in consumer driven and responsive supply chains: The case of processed fruit juice in Uganda. Paper presented at the African Economic Research Consortium (AERC) Faculty’s Research Conference, Arusha, Tanzania, December 1.

Hattingh, D., Russo, B., Sun-Basorun, A., \& Van Wamelen, A. (2012). The rise of African consumer: A report from McKinsey's Africa Consumer Insights Center. McKinsey and Company.

Hirekenchanagoudar, R. (2008). Consumer behaviour towards ready-to-eat food products. Unpublished thesis, University of Agriculture Sciences, Dharward (Institute), India.

Kalungi, N. (2012). Uganda's fruit juice consumption on the rise as dominant player battles for market. The Daily Monitor, Kampala, December 18.

Kim, J., \& Mueller, C. W. (1978a). Factor analysis: Statistical methods and practical issues (Quantitative Applications in the Social Sciences Series No. 14). Thousand Oaks: Sage Publications.

Kim, J., \& Mueller, C. W. (1978b). Introduction to Factor analysis: What it is and how to do it (Quantitative Applications in the Social Sciences Series No. 13). Thousand Oaks: Sage Publications.

Lee, P. Y., Lusk, K., Mirosa, M., \& Oey, I. (2015). An attribute prioritization-based segmentation of the Chinese consumer market for fruit juice. Food Quality and Preference, 46, 1-8. http://dx.doi.org/10.1016/j.foodqual.2015.06.016

Persistence Market Research, PMR (2015). Fruit juice and vegetable juice market: global industry analysis and forecast 2015 - 2021. [Online] Available: http://www.persistencemarketresearch.com/market-research/fruit-juice-and-vegetable-juice-m arket.asp (February 2, 2016)

Reardon, T. (2011). The global rise and impact of supermarkets: an international perspective. Paper presented at "The supermarket revolution in food: good, bad or ugly for the world's farmers, consumers and retailers?" Conference conducted by the Crawford Fund for International Agricultural Research, Parliament House, Canberra, Australia, August 14-16.

Sparke, K., \& Menrad K. (2009). Cross-European and functional food-related consumer segmentation for new product development. Journal of Food Product Marketing, 15(3), 213-230. http://dx.doi.org/10.1080/10454440902908142 


\section{Macrothink}

Business Management and Strategy

ISSN 2157-6068 2016, Vol. 7, No. 1

Uganda Investment Authority, UIA (2009). Investing in Uganda: investment potentials in fruit juice processing. Report. Kampala: UIA.

Weemaes, H. and Reithmuller P. (2001). What Australian consumers like about fruit juice: results from hedonic analysis. Paper presented at the World Food and Agribusiness Symposium, International Food and Agribusiness Management Association, Sydney, June 27-28.

Wright, L.T., Nancarrow, C., \& Kwok, P. M. H. (2001). A case study: food taste preferences and cultural influences on consumption. British Food Journal, 103(5), 348-357. http://dx.doi.org/10.1108/00070700110396321

\section{Copyright Disclaimer}

Copyright for this article is retained by the authors, with first publication rights granted to the journal.

This is an open-access article distributed under the terms and conditions of the Creative Commons Attribution license (http://creativecommons.org/licenses/by/3.0/). 